\title{
In vitro antiviral activity of propolis and Baccharis sp. extracts on animal herpesviruses
}

\author{
Atividade antiviral in vitro de extratos de própolis \\ e de Baccharis sp. sobre herpes vírus animal
}

\author{
Isabela Cristina Simoni ${ }^{1 *}(\mathbb{D})$, Bruna Aguiar ${ }^{1,2}$, Aline Martineli de Araujo Navarro', Rafael Martins \\ Parreira ${ }^{1,2}$, Maria Judite Bittencourt Fernandes ${ }^{1}$, Alexandra Christine Helena Frankland Sawaya ${ }^{3}$, \\ Oriana Aparecida Fávero²
}

\begin{abstract}
This study evaluated the in vitro antiviral activity of propolis and Baccharis sp. extracts on three animal herpesviruses (bovine, equine and swine). The propolis samples were produced by two species of bees. There was red and green propolis, which came from africanized Apis melifera, and a third type obtained from a native bee species, Tetragonisca angustula (jatai). The Baccharis extracts were obtained from four different species: $B$. oblongifolia, $B$. burchellii, B. dracunculifolia and $B$. uncinella. The maximum non-toxic concentration of the extracts was determined when no visible morphological changes were observed on the cells. These non-toxic concentrations were used in the antiviral tests. Antiviral activity was evaluated using a reduction assay of the cytopathic effect, which calculated the difference between treated and control virus titer by statistical analysis. Red propolis was active against the three herpesviruses and green propolis showed inhibition against the equine and swine herpesviruses. Conversely, jataí propolis showed no antiviral activity. Most extracts coming from male and female individuals of all of the Baccharis species showed antiviral activity against bovine and swine herpesviruses. Only the extract of the female specimen of B. oblongifolia was an inhibitor against equine herpesvirus.
\end{abstract}

KEYWORDS: antiviral; propolis; Baccharis; animal herpesviruses.

\begin{abstract}
RESUMO: O trabalho avaliou a atividade antiviral in vitro de própolis e espécies de Baccharis sobre três herpes vírus animais (bovino, equino e suíno). As própolis foram produzidas por duas espécies de abelhas. Pela Apis melifera (abelha africanizada) foram obtidas duas própolis, vermelha e verde, e uma terceira foi obtida pela abelha nativa Tetragonisca angustula (abelha jataí). Os extratos de Baccharis foram obtidos de 4 espécies diferentes: B. oblongifolia, B. burchellii, $B$. dracunculifolia e $B$. uncinella. A concentração máxima não tóxica dos extratos foi determinada pela ausência de alteraçôes morfológicas nas células, e essas concentraçóes entâo utilizadas nos testes antivirais. A atividade antiviral foi avaliada pela reduçáo do efeito citopático e calculada a partir da diferença entre o título viral do tratado pelo controle e feita a análise estatística. A própolis vermelha foi ativa contra os três herpes vírus, e a própolis verde apresentou inibição contra os herpes vírus equino e suíno, enquanto a própolis da abelha jataí não apresentou atividade antiviral. A maioria dos extratos dos indivíduos masculinos e femininos de todas as espécies de Baccharis apresentou atividade antiviral contra os herpes vírus bovino e suíno. Apenas o extrato do indivíduo feminino de B. oblongifolia foi inibidor contra o herpes vírus equino.
\end{abstract}

PALAVRAS-CHAVE: antiviral; própolis; Baccharis; herpes vírus animal.

\footnotetext{
'Instituto Biológico, Centro de Pesquisa e Desenvolvimento de Sanidade Animal - São Paulo (SP), Brazil ${ }^{2}$ Universidade Presbiteriana Mackenzie - São Paulo (SP), Brazil

${ }^{3}$ Departamento de Biologia Vegetal, Instituto de Biologia, Universidade Estadual de Campinas (UNICAMP) - Campinas (SP), Brazil *Corresponding author: simoni@biologico.sp.gov.br; isabelasimoni@gmail.com 


\section{INTRODUCTION}

Viral infections are important to study because they are capable of affecting many individuals in a short period of time, and have high rates of morbidity and mortality. Viral diseases in animals include those caused by equine, bovine and swine herpesviruses and they are responsible for diseases that cause great economic impact. Equine herpesvirus type 1 (EqHV-1) causes equine rhinopneumonitis, resulting in neurological disorders and miscarriages. The main way the virus is transmitted is when susceptible hores enhail aerosols (PENA et al., 2006). Herpesvirus type 1 (SuHV-1) is the causative agent of Aujeszky's or pseudorabies disease, and is present worldwide, including in Brazil (SILVA et al., 2005). SuHV-1 is transmitted by susceptible animals' direct or indirect contact with contaminated secretions or other infected animals. Bovine herpesvirus type 1 (BoHV-1) is a virus that is present throughout the world, including in Brazil, and causes several clinical manifestations that are known as infectious bovine rhinotracheitis, balanoposthitis or infectious pustular vulvovaginitis. After the primary infection, BoHV-1 can replicate both in the respiratory tract and in the genital tract, leading to abortion. This demonstrates the great economic importance of studying alternative methods for combating BoHV-1 (ACKERMANN; ENGELS, 2006). BoHV-1 can be transmitted either through direct or indirect contact between animals, it may be present in the semen of infected bulls, and it can be transmitted by natural mating or by artificial insemination.

Usually infectious diseases are controlled by the use of vaccines, which do not work when diseases are already present. As such, it is a challenge to find new ways to combat viral infections, especially those that affect animals. In addition, it is possible for the systemic use of antivirals in animals to cause harm to their owners (DEZENEGINI et al., 2010). In this regard, natural products are important for the discovery of new drugs. However, because of the close relationship between the virus and the host cell, this search is difficult and needs to be more rational, taking advantage of the antiviral potential of natural products with other known biological properties.

In recent decades, there has been a growth in research on alternative therapies and the use of natural products, such as propolis. Propolis is traditionally used in folk medicine, mainly for its antibacterial effect. Antifungal, antiviral, anti-inflammatory and immunostimulant properties have also been described in relation to this resin (FERNANDES et al., 2007).

Propolis is the generic term used to denominate resinous material collected by bee species, among them Apis mellifera and Tetragonisca angustula, that use this substance to protect themselves against insects and microorganisms. (MARCUCCI, 1996). Tetragonisca angustula is a small stingless bee, popularly known as jatai, which is present in the north, northeast, south and southeast regions of Brazil. Apis mellifera is currently found in Brazil and is considered to be an Africanized bee, due to the cross between African and European varieties. Propolis is an apicultural product, and bees produce it from secretions of trees, flowers, leaves and pollen- a complex set of substances (WOISKY; SALATINO, 1998). Some factors such as the ecology of the region where the propolis was collected and the plant origin of this resin can influence its chemical composition (PARK et al., 1998).

Among the diversified flora found in our country, it is suggested that the Dalbergia ecastophyllum, popularly known as "howler-tail", Araucaria angustifolia (Bertoli) Otto Kuntze ("Paraná pine”), Eucalyptus citriodora Hook ("lemon eucalyptus") and Baccharis species, could be important sources for the production of this resinous material (SILVA et al., 2008).

Baccharis is a genus that presents dioecious individuals of the Asteraceae family, which occurs in South America. It has a wide variety of biological activities, but there are few reports in the literature with regard to the B. burchellii and B. oblongifolia species. Some studies have been conducted with both propolis and Baccharis species on their potential to fight against diseases caused by viruses. EL-HADY; HEGAZI (2002) described the antiviral activity against bursal infectious disease virus (IBVD) and reovirus from propolis samples obtained in different provinces of Egypt. PALOMINO et al. (2002) found antiviral activity against HIV in the extract of $B$. trinervis and BUDEL; DUARTE (2008) found that B. uncinella extract was active against HSV.

In this context, the objective of the present study was to analyze the in vitro antiviral potential of three types of propolis obtained from two different regions of Brazil to fight against equine, porcine and bovine herpesvirus, and to compare the inhibitory effect of propolis obtained from two species of bees: Africanized Apis mellifera and the native stingless bee, Tetragonisca angustula. In addition, the aim of this study was to investigate the antiviral activity of plant species, such as the raw extracts of aerial parts of Baccharis species, in cell lines against animal herpes viruses.

\section{MATERIALS AND METHODS}

\section{Cell Lines and Viral Samples}

The Vero (african monkey green kidney) and MDBK (Mardin Darby bovine kidney) cell lines, both maintained in Eagle's minimal essential medium (MEM), plus 10\% fetal bovine serum (FBS), were used.

The equine herpesvirus (EqHV-1) strain A4/72 with a mean titer of $10^{5.82} \mathrm{TCID}_{50 / \mathrm{mL}}$, the swine herpesvirus (SuHV-1) Nova Prata strain with a mean titer of $10^{6.0} \mathrm{TCID}_{50 / \mathrm{mL}}$ and the bovine herpesvirus (BoHV-1) strain Los Angeles (LA) with an average titre of $10^{6.0} \mathrm{TCID}_{50 / \mathrm{mL}}$ were used. 


\section{Propolis}

The samples were obtained in the following places and dates: red propolis was produced in November 2009, in Maceió, by Apis mellifera; green propolis was produced in December, 2009, in Atibaia, by Apis mellifera; and Jataí propolis was produced in November, 2009, in Icém - SP, by Tetragonisca angustula. The dried ethanolic extracts of the propolis samples were obtained by maceration in ethanol. Then they were filtered and the solvent was evaporated. Each dry ethanolic extract of propolis was solubilized with 5\% DMSO (Dimethylsulfoxide) and diluted in deionized water and in MEM to give a final concentration of $4,000 \mu \mathrm{g} . \mathrm{mL}^{-1}$. Solutions of $5 \%$ DMSO that did not have propolis were used as a control of the solvent.

\section{Preparation of plant extracts}

Samples of male and female specimens of Baccharis (Table 1) were collected in the same region of the Umuarama Condomínio, in the municipality of Campos do Jordão. The Baccharis burchellii Baker Vouchers were deposited in the Herbário do Instituto Florestal, No. SPSF44895 and SPSF44896, respectively; and Baccharis oblongifolia (Ruiz \& Pav.) Pers. were deposited in the Herbário do Instituto Florestal, SPSF41684. The collections were performed on October 24, 2009. The specimens of Baccharis dracunculifolia DC. were kindly provided by the Fundação Ezequiel Dias-FUNED, MG and were collected on April 29, 2011. The specimens of Baccharis uncinella DC. were collected on June 11, 2011.

The fresh leaves were ground in 10\% hydroalcoholic solution of $99.5^{\circ} \mathrm{GL}$ ethanol and cold distilled water according to the proportion of $20 \mathrm{~g}$ of plant material in $100 \mathrm{~mL}(\mathrm{w} / \mathrm{v})$ of hydroalcoholic solution. The dried leaves were prepared in the proportion of $10 \mathrm{~g}$ of plant material in $100 \mathrm{~mL}(\mathrm{w} / \mathrm{v})$ of hydroalcoholic solution. These plant materials were refrigerated for 24 hours, filtered through gauze, filtered through filter paper, frozen, lyophilized, and stored at room temperature. At the time of use, the lyophilized samples were prepared in MEM without SFB for the assays in the concentration of $4,000 \mu \mathrm{g} \cdot \mathrm{mL}^{-1}$.

\section{Cytotoxicity assay}

The maximum non-toxic concentration (MNTC) of plant extracts and propolis was evaluated in Vero and MDBK cells.
In 96-well sterile disposable microplates, $3.0 \times 10^{4}$ cells/ well were seeded. After 24 hours of incubation at $37^{\circ} \mathrm{C}$ in a humidified 5\% $\mathrm{CO}_{2}$ atmosphere, the supernatant medium was discarded and $100 \mu \mathrm{L}$ different dilutions of the plant extracts and the DMSO control solution were placed in each well with three replicates for each dilution. The microplates were then incubated again for at least 96 hours. The highest concentration that did not induce detectable morphological changes in the cells under the optical inverted microscope was considered to be the MNTC. Serial dilutions ranged from 4,000 to $3.9 \mu \mathrm{g} / \mathrm{mL}$.

\section{Antiviral activity assay}

Antiviral activity was performed by the cytopathic effect inhibition method described in KOSEKI et al. (1990). Microplates were seeded with $3.0 \times 10^{4}$ cells in $100 \mu \mathrm{L}$ for each well. After 24 hours of incubation at $37^{\circ} \mathrm{C}$ in a $5 \% \mathrm{CO}_{2}$ environment, the supernatant medium was discarded and the diluted plant extracts and propolis in the MNTC and the DMSO control were placed in each well. Viral suspensions were then added in $\log$ dilutions, and the microplates were incubated again for at least 96 hours. The viral titre $\left(\mathrm{TCID}_{50}\right)$ was calculated by the REED; MUENCH (1938) method and antiviral activity was calculated by the difference of the viral titers being treated with the extracts $(\mathrm{T})$ and the control untreated-infected cells (C), expressed as percentage of inhibition (IP), according to the formula PI=[1-(Titer of treated cells(T)/Titer of the control cells $(\mathrm{C})] \times 100$. To calculate the maximum reduction, the percentage of reduction was obtained from the difference of the titers between the extract and control. The values of the mean titers were then used for an analysis of variance ANOVA and using the Tukey test, considering that the differences were statistically significant values of $\mathrm{p}<0.05$.

\section{RESULTS}

The cytotoxicity and antiviral activity assays of the three propolis samples were evaluated in the MDBK cell line against bovine and swine herpeviruses and in the Vero cell line against equine herpesvirus. Table 2 shows the results of cytotoxicity and antiviral activity for the three propolis types. Green propolis was less

Table 1. Specie of Baccharis.

\begin{tabular}{lccc} 
Scientific name & Common name & Type of extract & Collection date \\
Baccharis burchellii Baker & Alecrim-carqueja & Fresh aerial parts & $10 / 24 / 2009$ \\
\hline Baccharis oblongifolia (Ruiz \& Pav.) Pers. & Vassoura-da-folha-longa & Fresh aerial parts & $10 / 24 / 2009$ \\
\hline Baccharis dracunculifolia DC. & Alecrim-do-campo & Dry aerial parts & $04 / 29 / 2011$ \\
\hline Baccharis uncinella DC. & Vassoura & Fresh aerial parts & $06 / 11 / 2011$ \\
\hline
\end{tabular}


cytotoxic, with MNTC $500 \mu \mathrm{g} \cdot \mathrm{mL}^{-1}$ in MDBK. Red propolis and Jataí propolis presented the same cytotoxicity with a MNTC of $250 \mu \mathrm{g} \cdot \mathrm{mL}^{-1}$. In relation to the MNTC in Vero, red propolis was the most cytotoxic with a MNTC of $125 \mu \mathrm{g} \cdot \mathrm{mL}^{-1}$, in relation to green propolis and Jataí, both with a MNTC of $500 \mu \mathrm{g} \cdot \mathrm{mL}^{-1}$.

Regarding the antiviral assay, Table 2 shows that red propolis showed antiviral activity against swine herpesvirus with $97.8 \%$ inhibition in relation to the control, which corresponds to a maximum reduction of 45.7 times the viral titre. With regard to the equine herpesvirus, red propolis presented an inhibition of $87.7 \%$, and a significant difference in relation to the titer of the virus control, corresponding to a maximum reduction of 8.1 times. With regard to the bovine herpesvirus, red propolis had a viral inhibition of 95.8 and a maximum reduction of 24 times. Green propolis presented $85.2 \%$ inhibition against equine herpesvirus and corresponded to a maximum reduction 6.8 times in relation to the control virus. The result against swine herpesvirus showed an inhibition of $96.1 \%$ and a maximum reduction of 25.7 times. In both cases there was a significant difference in relation to the virus control $(\mathrm{p}<0.05)$. The green propolis presented no significant difference against bovine herpesvirus in relation to the mean titer of the control.

Jataí propolis presented $73.7 \%$ inhibition percentage against swine herpesvirus, but had no significant difference in relation to the control. However, the Jataí propolis extracts showed no inhibition against equine and bovine herpesviruses.

Table 3 presents the cytotoxicity and antiviral activity results of Baccharis species extracts. The three most cytotoxic extracts against Vero cells were: the $B$. oblongifolia male specimen (MNTC of $3.9 \mu \mathrm{g} \cdot \mathrm{mL}^{-1}$ ) and the two extracts of B. uncinella male and female specimens (MNTC $7.8 \mu \mathrm{g} \cdot \mathrm{mL}^{-1}$ ). Most of the extracts showed lower cytotoxicity in the MDBK line than in the Vero line, indicating that the latter is more sensitive. The extracts with the highest cytotoxicity were B. oblongifolia and B. uncinella (62.5 $\left.\mu \mathrm{g} \cdot \mathrm{mL}^{-1} \mathrm{MNTC}\right)$. The extract of the female specimen of $B$. burchellii had the lowest MNTC of $500 \mu \mathrm{g} \cdot \mathrm{mL}^{-1}$, when compared to all other extracts. The extract of the male specimen of $B$. dracunculifolia was more cytotoxic than the female specimen. In relation to B. uncinella, the female specimen had a MNTC of $62.5 \mu \mathrm{g} \cdot \mathrm{mL}^{-1}$, and was thus more cytotoxic than the male specimen.

Table 3 also shows the percentages of viral inhibition from extracts of male and female individuals of the Baccharis species against animal herpesviruses. Regarding the equine herpesvirus, only the extract of the female specimen of B. oblongifolia presented antiviral activity with an inhibition of $98.2 \%$, corresponding to a maximum reduction of 55 times in relation to the control virus. As for bovine herpesvirus, all of the extracts presented antiviral activity. B. burchellii was the highest, obtaining $100 \%$ inhibition with extracts of both female and male specimens. The B. oblongifolia extract of female plants also showed a $100 \%$ inhibition, and the male specimen showed an inhibition of $98.6 \%$, with a maximum reduction of 74 times in relation to the control. Regarding $B$. dracunculifolia, the female specimen presented antiviral activity with a maximum reduction of 214 times, and the male specimen 68 times the control. Only the

Table 2. Maximim non-toxic concentration (MNTC) of the three types propolis tested in MDBK and Vero cell lines, and the percentage of inhibition (PI) against equine (EqHV-1), swine (SuHV-1) and bovine (BoHV-1) herpesviruses.

\begin{tabular}{lccccc} 
Type of propolis & $\begin{array}{c}\text { MNTC VERO } \\
(\mu \mathrm{g} / \mathrm{mL})\end{array}$ & $\begin{array}{c}\text { PI\% } \\
\text { EqHV-1 }\end{array}$ & $\begin{array}{c}\text { MNTC MDBK } \\
(\mu \mathrm{g} / \mathrm{mL})\end{array}$ & $\begin{array}{c}\text { PI\% } \\
\text { SuHV-1 }\end{array}$ & $\begin{array}{c}\text { IP\% } \\
\text { BoHV-1 }\end{array}$ \\
\hline Red & 125 & $87.7^{\mathrm{a}}$ & 250 & $97.8^{\mathrm{a}}$ & $95.8^{\mathrm{a}}$ \\
\hline Green & 500 & $85.2^{\mathrm{a}}$ & 500 & $96.1^{\mathrm{a}}$ & 58.3 \\
\hline Jataí & 500 & 0 & 250 & 73.7 & 58.3 \\
\hline
\end{tabular}

${ }^{a}$ significant values $p<0.05$

Table 3. Maximim non-toxic concentration (MNTC) of the species of Baccharis tested in MDBK and Vero cell lines; the percentage of inhibition (PI) against equine (EqHV-1), swine (SuHV-1) and bovine (BoHV-1) herpesviruses.

\begin{tabular}{|c|c|c|c|c|c|}
\hline $\begin{array}{l}\text { Name and type } \\
\text { of species }\end{array}$ & $\begin{array}{c}\text { MNTC } \\
\text { VERO }\left(\mu \mathrm{g} \cdot \mathrm{mL}^{-1}\right)\end{array}$ & $\begin{array}{c}\text { PI \% } \\
\text { EqHV-1 }\end{array}$ & $\begin{array}{c}\text { MNTC } \\
\text { MDBK }\left(\mu \mathrm{g} \cdot \mathrm{mL}^{-1}\right)\end{array}$ & $\begin{array}{c}\text { PI \% } \\
\text { BoHV-1 }\end{array}$ & $\begin{array}{c}\text { PI \% } \\
\text { SuHV-1 }\end{array}$ \\
\hline B. oblongifolia ô & 3.9 & 82.2 & 62.5 & $98.6^{a}$ & $96.8^{\mathrm{a}}$ \\
\hline B. oblongifolia우 & 62.5 & $98.2^{a}$ & 250 & $100^{a}$ & $100^{a}$ \\
\hline B. burchellii ${ }^{\lambda}$ & 62.5 & 81.8 & 250 & $100^{a}$ & $100^{a}$ \\
\hline B. burchellii ㅇ & 31.2 & 81.8 & 500 & $100^{a}$ & $100^{a}$ \\
\hline B. dracunculifolia $\widehat{\partial}$ & 125 & 68.4 & 125 & $98.5^{a}$ & 82.6 \\
\hline B. dracunculifolia + & 250 & 78.1 & 250 & $99.5^{a}$ & $99^{a}$ \\
\hline B. uncinella ${ }^{\top}$ & 7.8 & 30.8 & 250 & $99.9^{a}$ & $99.9^{a}$ \\
\hline B. uncinella $q$ & 7.8 & 0 & 62.5 & $98.2^{a}$ & $98.2^{\mathrm{a}}$ \\
\hline
\end{tabular}

${ }^{a}$ significant values $p<0.05$ 
extract of the male specimen of $B$. uncinella showed a maximum reduction of 5,500 times compared to the control virus. The results obtained against the swine herpesvirus were very similar to those obtained with the bovine herpesvirus, and the extracts of $B$. burchellii individuals showed the highest antiviral activity among the extracts tested with $100 \%$ viral inhibition. The same was observed with the extract of the female individual of B. oblongifolia. The male individual presented a PI of $96.8 \%$ and a maximum reduction of 31.6. Regarding $B$. dracunculifolia, only the female specimen presented antiviral activity with a maximum 100-fold reduction. On the other hand, only the extract of the male specimen of $B$. uncinella showed inhibition against the swine herpesvirus with a maximum reduction of 1,000 times in relation to the control virus.

\section{DISCUSSION}

In this work, propolis from different regions of Brazil, produced by bees of two different species were tested against bovine, equine and swine herpesviruses. Red propolis collected in Alagoas, and green propolis collected in Atibaia, SP, were obtained from $A$. mellifera bees. The Jataí propolis collected in Icém was obtained from a species of native stingless bee, $T$. angustula.

The Brazilian red propolis collected in northeastern Brazil appears in regions with the common occurrence of a local plant (D. ecastophyllum) and therefore, is the probable plant source of the red propolis used in this work. This type of propolis has flavonoids as its main chemical constituents (SILVA et al., 2008; TRUSHEVA et al., 2006). According to the mass spectrometry of the electrospray ionization from the red propolis of this work, isoflavones and prenylated benzophenones were identified (SAWAYA et al., 2006, SAWAYA et al., 2010; LÓPEZ et al., 2014).

The therapeutic effects of propolis have been attributed to the various phenolic compounds among them. Flavonoids can be considered the main class of compounds. According to MANRIQUE; SANTANA (2008), propolis produced by the species $T$. angustula, also known as Jataí propolis, has a low concentration of flavonoids. A study by TAVARES et al. (2010) has demonstrated that green propolis has flavonoids, whereas according to NUNES et al. (2009) red propolis is composed of several phenolic compounds, flavonoids, anthraquinones and phenols.

VYNOGRAD et al. (2000) showed that the antiviral activity of propolis against genital herpesvirus (HSV) was attributed to flavonoids. A high inhibitory effect of propolis against poliovirus was also attributed to the presence of flavonoids (AMOROS et al., 1992). GONÇALVES et al. (2001) showed that the leaf extract of Vitex polygama (Verbenaceae) was active against the acyclovir-resistant HSV strain, an effect attributed to flavonoids.
The results obtained in the present work show that red propolis presented the best antiviral activity, and suggest that the flavonoids and possibly other bioactive components present in the red propolis may be involved in this activity. Jataí propolis did not achieve significant inhibition values against any of the tested herpesviruses. The results obtained with Jataí propolis are probably due to the fact that this propolis was produced by T. angustula, unlike the green and red propolis, and does not have the same chemical composition (SAWAYA et al., 2006).

Green propolis from São Paulo has mainly B.dracunculifolia (ALENCAR et al., 2005) resins, and it is made up of mainly flavonoids and phenylpropanoids, according to mass spectrometry with electrospray ionization (SAWAYA et al., 2010). Thus, like red propolis, the antiviral activity of green propolis may possibly be attributed to the presence of these phenolic compounds.

The antiviral activity of Baccharis species has been reported, but few articles are found in the literature. According to BUDEL; DUARTE (2008), B. uncinella extract was active against HSV. In the study by PALOMINO et al. (2002), B. trinervis extract showed antiviral activity against HIV and HSV when simultaneously added to the virus inoculation. In our work, both Baccharis and propolis extracts were added to the cells at the time of viral infection, indicating that the observed inhibition may be related to the initial steps of virus replication in adsorption and/or penetration.

SERKEDJIEVA et al., 1992 observed that the pre-treatment of propolis in MDCK cells on influenza virus was not active, but was effective when added at the time of viral infection. MUKHTAR et al., 2008 also reported that simultaneous treatment of $B$. dracunculifolia extract and propolis was the most effective in inhibiting poliovirus in HEP-2 cells. These findings corroborate those observed in the present study, but it is not possible to rule out the possibility that this inhibition is related to other effects such as virucidal action or the late stages of viral replication and thus, more detailed research on the action mechanisms of green and red propolis, as well as Baccharis extracts is needed. In this work, it was also verified that although the extracts of the male and female specimens of B. oblongifolia and $B$. burchellii showed antiviral activity against bovine and swine herpesvirus, the extracts of female individuals had a higher percentage of viral inhibition than those of the male individuals of their respective species, and the same occurred with $B$. dracunculifolia. However, this did not occur with the extracts of $B$. uncinella species. In this case, the male individual presented greater inhibition of the virus than the female one. Thus, the difference between the inhibitory potential of the female and the male Baccharis may be related to differences in the composition of the extracts. Female individuals of dioecious plants, such as Baccharis species, accumulate more energy and nutrients than male individuals because of reproduction (CARNEIRO et al., 
2006). The female plants also expend greater amounts of energy in the maintenance of the reproductive structures, which generate an increase of the ratio of carbon and nutrients in the vegetative parts of the plant. This excess carbon is used in the production of chemical defense compounds (ARAUJO et al., 2003).

\section{CONCLUSIONS}

Red and green propolis produced by $A$. mellifera showed significant antiviral activity against herpesviruses in animals. However, Jatai propolis produced by T. angustula did not present antiviral activity against any of the herpesviruses. Extracts from male and female specimens of the Baccharis species showed antiviral activity mainly against bovine and porcine herpesviruses, but there was a difference between the inhibitory potential of the female individuals in relation to the male individuals.

\section{ACKNOWLEDGMENTS}

We thank the National Council for Scientific and Technological Development (CNPq), for granting scholarships for Scientific Initiation to Aline Martineli de Araújo and Bruna Aguiar.

| | | | | | | | | | | | | | | | | | | | | | | | | | | | | | | | | | | | | | | | | | | | | | | | | | | | | | | | | | | | | | | | | | | | | | | | | | | | | | | | | | | | | | | | | | | | | | | | | | | | | | | | | | | | | | | | | | | | | | | | | | | | | | | | | | | | | | | | | | | | | | | | | | | | | | | | | | | | | | | | | | | | | | | | | | | | | | | | | | | | | | | | | | | | | | | | | | | | | | | | | | | | | REFERENCES

ACKERMANN, M.; ENGELS, M. Pro and contra IBR eradication. Veterinary Microbiology, v. 1 13, p.293-302, 2006.

ALENCAR, S.M.; AGUIAR, C.L.; PAREDES-GUZMAN, J.; PARK, Y.K. Composição química de Baccharis dracunculifolia, fonte botânica das própolis dos estados de São Paulo e Minas Gerais. Ciência Rural, v.35, n.4, p.909-915, 2005.

AMOROS, M.; SAUVAGER, F.; GIRRE, L.; CORMIER, M. In vitro antiviral activity of propolis. Apidologie,v.23, n.3, p.231-240, 1992.

ARAUJO, A.P.A.; CARNEIRO, M.A.A; FERNANDES, G.W. Efeitos do sexo, do vigor e do tamanho da planta hospedeira sobre a distribuição de insetos indutores de galhas em Baccharis pseudomyriocephala Teodoro (Asteraceae). Revista Brasileira de Entomologia, v.47, n.4, p.483-490, 2003.

BUDEL, J.M.; DUARTE, M.R. Estudo farmacobotânico de folha e caule de Baccharis uncinella DC. Asteraceae. Latin American Journal of Pharmacy, v.27, n.5, p.740-746, 2008.

CARNEIRO, M.A.A.; FERNANDES, G.W.; SOUZA, O.F.F.; SOUZA, W.V. Sex-mediated herbivory by galling insects on Baccharis concinna (Asteraceae). Revista Brasileira de Entomologia, v.50, n.3, p.394-398, 2006.

DEZENGRINI, R.; DA SILVA, S.C.; WEISS, M.; LUIZ C. KREUTZ, L.C.; WEIBLEN, R.; FLORES, E.F. Atividade de três drogas antivirais sobre os herpesvírus bovino tipos 1,2 e 5 em cultivo celular. Pesquisa Veterinária Brasileira, v.30, n.10, p.855-860, 2010.

EL-HADY, A.F.K.; HEGAZI, A.G. Egyptian Propolis: 2. Chemical composition, antiviral and antimicrobial activities of East Nile Delta Própolis. Zeitschrift für Naturforschung C., v.57, n.3-4, p.386-394, 2002.
FERNANDES, F.F.; DIAS, A.L.T.; RAMOS, C.L.; IKEGAKI, M.; SIQUEIRA, A.M.; FRANCO, M.C. The in vitro antifungal activity evaluation of propolis $\mathrm{G} 12$ ethanol extract on Cryptococcus neoformans. Revista do Instituto de Medicina Tropical, São Paulo, v.49, n.2, p.93-95, 2007.

GONÇALVES, J.L.S.; LEITÃO, S.G.; DELLE MONACHE, F.; MIRANDA, M.M.F.S.; SANTOS, M.G.M.; ROMANOS, M.T.V.; WIGG, M.D. In vitro antiviral effect of flavonoid-rich extracts of Vitex polygama (Verbenaceae) against acyclovir-resistant herpes simplex virus type 1. Phytomedicine, v.8 n.6, p. 477-480. 2001.

LÓPEZ, B.G.-C.; SCHMIDT, E.M.; EBERLIN, M. N. SAWAYA, A.C.H.F. Phytochemical markers of different types of red propolis. Food Chemistry, v.146, p.174-180, 2014.

MARCUCCI, M.A. Propriedades biológicas e terapêuticas dos constituintes químicos da própolis. Química Nova, v.19, n.5, p.529-536, 1996.

MANRIQUE, A.J.; SANTANA, W.C. Flavonoides, actividades antibacteriana y antioxidante de propóleos de abejas sin aguijón, Melipona quadrifasciata, Melipona compressipes, Tetragonisca angustula y Nannotrigona sp. de Brasil y Venezuela. Zootecnia Tropical, v.26, n.2, p.157-166, 2008.

MUKHTAR, M.; ARSHAD, M.; AHMAD, M.; POMERANTZ, R.J.; WIGDAHL, B.; PARVEEN,Z. Antiviral potentials of medicinal plants. Virus Research, v.131, n.2, p.111-120, 2008.

NUNES, L.C.C. Variabilidade sazonal dos constituintes da própolis vermelha e bioatividade em Artermia salina. Revista Brasileira de Farmacognosia, v.19, n.2b, p.524-529, 2009.

PALOMINO, S.S.; ABAD, M.J.; BEDOYA, L.M.; GARCÍA, J.; GONZALES, E.; CHIRIBOGA, X.; BERMEJO, P.; ALCAMI, J. Screening of 
South American Plants against Human Immunodeficiency Virus: Preliminary Fractionation of Aqueous Extract from Baccharis Trinervis.Biological and Pharmaceutical Bulletin, v.25, n.9, p. $1147-1150,2002$.

PENA, L.J.; PENA, D.A.; BARRIOS, P.R.; DALE, R.; LAMÊGO, M.R.A.; MORAES, M.P. Levantamento soro-epidemiológico da infecção pelo vírus da Anemia Infecciosa Equina, da Influenza Equina-2 e do Herpesvírus Equino- 1 em rebanhos do sul do Estado do Pará, Brasil. Brazilian Journal of Veterinary Research and Animal Science, v.43, n.4, p.537-542, 2006.

REED, L.J.; MUENCH, H. A simple method of stimating fifty per cent and point. American Journal of Hygiene, v. 18 , p.493-497, 1938.

SAWAYA, A.C.H.F.; CUNHA, I.B.S.; MARCUCCI, M.C.; RODRIGUES, R.F.D.; EBERLIN, M.N. Brazilian propolis of Tetragonisca angustula and Apis mellifera. Apidologie, v.37, p.398-407, 2006. Available from: http://www.edpsciences.org/apido. Accessed on: Dec. 122016.

SAWAYA, A.C.H.F.; ABDELNUR, P.V.; EBERLIN, M.N.; KUMAZAWA, S.; AHN, M.R.; BANGD, K-S.; NAGARAJAE, N.; BANKOVA, V.S.; AFROUZANG, $\mathrm{H}$. Fingerprinting of propolis by easy ambient sonic-spray ionization mass spectrometry. Talanta, v.81, n.1, p. 100-108, 2010.

SERKEDJIEVA, J.; MANOLOVA, N.; BANKOVA, V. Anti-influenza Virus Effect of Some Propolis Constituents and Their Analogues (Esters of Substituted Cinnamic Acids). Journal of Natural Products, v.55, n.3, p.294-297, 1992.
SILVA, A.D.; SORTICA, V.A.; BRAGA, A.C.; SPILKI, F.R.; FRANCO, A.C.; STEVES, P.A.; RIJESEWIJK, F.; ROSA, J.C.A.; BATISTA, H.C.R.; OLIVEIRA, A.P.; ROEHE, P.M. Caracterização antigênica e molecular de oito amostras do vírus da doença de Aujeszky isoladas no estado do Rio Grande do Sul em 2003. Pesquisa Veterinária Brasileira, v.25, n.1, p.21-25, 2005.

SILVA, B.B.; ROSALEN, P.L.; CURY, J.A.; IKEGAKI, M.; SOUZA, V.C.; ESTEVES, A.; ALENCAR, S.M. Chemical Composition and Botanical Origin of Red Propolis, a New Type of Brazilian Propolis. Evidence-Based Complementary and Alternative Medicine, v.5, n.3, p.313-316, 2008.

TAVARES, LC.; LEMOS T.L.G.; ARRIAGA, A.M.C.; SANTIAGO, G.M.P.; BRAZ-FILHO, R. Estudo químico de uma amostra de própolis verde de Passa Quatro, Minas Gerais, Brasil. Química Nova, v.33, n. 10, p.2051-2054, 2010.

TRUSHEVA, B.; POPOVA, M.; BANKOVA, V.; SIMOVA, S.; MARCUCCI, M.C.; MIORINP. L.; PASIN, F.R.; TSVETKOVA, I. Bioactive Constituents of Brazilian Red Propolis. Evidence-Based Complementary and Alternative Medicine, v.3, n.2, p.249-254, 2006.

VYNOGRAD, N.; VYNOGRAD, I.; SOSNOWSKI, Z. A comparative multi-centre study of the efficacy of propolis, acyclovir and placebo in the treatment of genital herpes (HSV). Phytomedicine, v.7. n. 1, p. 1-6, 2000.

WOISKY, R.G.R.; SALATINO, A. Analysis of propolis: some parameters and procedures for chemical quality control. Jounal of Apicultural Research, v.37, n.2, p.99-105, 1998. 